\title{
Athanasius Kircher and Terrestrial Magnetism: The Magnetic Map
}

\author{
Agustín Udías, S.J. \\ Universidad Complutense de Madrid \\ agustinudias@gmail.com
}

\begin{abstract}
Athanasius Kircher paid special attention to magnetism, more specifically terrestrial one, in his work Magnes sive de arte magnetica. Other Jesuits of his time, such as Garzoni and Cabeo, also wrote on this subject. Kircher studied in particular magnetic declination and its possible use to determine geographical longitudes. At his time, this was an important subject for long sea journeys. First, he collected a large number of observations of magnetic declination from different sources in three tables and two lists with a total of 518 values, among them forty-three made by Jesuits. Kircher proposed that a magnetic map could be made based on these observations, but he did not do it. From Kircher's observations a map of magnetic declination has been drawn and it is presented here. Kircher discussed the causes of declination and presented a model for the origin of the magnetic field of the Earth, which differed from that proposed by Gilbert. Kircher finally considered magnetism as a cosmic force with its origin in God.
\end{abstract}

\section{Keywords}

Athanasius Kircher - Magnes - terrestrial magnetism - magnetic declination William Gilbert - magnetic map - origin of Earth's magnetism - magnetic cosmic force

Athanasius Kircher (1602-80) was born in the small town of Geisa, near Fulda (modern-day Germany), where his father Johann Kircher administered the affairs of the prince-abbot of Fulda during the difficult times of the Protestant

(C) AGUSTÍn UdíAS, S.J., LEIDEN, 2020 | DOI:10.1163/22141332-00702002

This is an open access article distributed under the terms of the prevailing CC-BY-NC-ND 4.0 license. 
Reformation. ${ }^{1}$ Kircher studied at the Jesuit college of Fulda and, in 1616, joined the Jesuits at the novitiate of Paderborn. These were difficult times due to the Thirty Years' War between Catholics and Protestants in German-speaking lands. Because of this, Kircher had to leave Paderborn in 1622 and travel to Münster and then to Cologne and Koblenz, where he finished his studies in philosophy. During these studies, Kircher began to get interested in languages and mathematics, two subjects that would become his lifelong passion.

In line with the new developments in early modern science, Jesuit colleges had, since their beginning in the middle of the sixteenth century, brought in the teaching of mathematics as an important subject, which was a novelty at that time. In particular, Christopher Clavius (1537-1612), professor of mathematics at the prestigious Roman College from 1567 to 1595 , initiated the interest in mathematics and thus began Jesuit tradition in science. Clavius's insistence on the importance of teaching mathematics was finally accepted in the Ratio studiorum, the standard program for all Jesuit schools. Consequently, mathematics, which at that time also included astronomy, mechanics, optics, and other applications to natural phenomena, was a required subject in all major Jesuit colleges. ${ }^{2}$ Clavius's first successor at the Roman College was Christoph Grienberger (1564-1636), who was mainly interested in astronomy. He is credited with being among the first to use the equatorial mounting of telescopes, which allows a better observation of the heavenly objects, and with the initiation of a new catalogue of stars based on telescopic observations.

In 1624, Kircher traveled to Heiligenstadt, where he became professor of mathematics and also taught Hebrew and Syriac languages. In 1630, he studied theology at Mainz, and after finishing these studies, he went to teach

1 Literature on Kircher is very abundant. See, for example: Conor Reilly, Athanasius Kircher S. J., Master of a Hundred Arts (1602-1680) (Rome: Edizioni del Mondo, 1974); John Fletcher, ed., Athanasius Kircher und seiner Beziehungen zum gelehrten Europa seiner Zeit (Wiesbaden: Otto Harrassowitz, 1988); Ignacio Gómez de Liaño, Athanasius Kircher, itinerario del éxtasis o las imágenes de un saber universal (Madrid: Siruela, 2001); Paula Findlen, ed., Athanasius Kircher: The Last Man Who Knew Everything (London: Routledge, 2004); Joscelyn Godwin, Athanasius Kircher's Theatre of the World: The Life and Work of the Last Man to Search for Universal Knowledge (Rochester, VT: Inner Traditions, 2009); John E. Fletcher, A Study of the Life and Works of Athanasius Kircher "Germanus incredibilis," ed., Elizabeth Fletcher (Leiden: Brill, 2011).

2 Luce Girard, ed., Les jésuites à la Renaissance: Système éducatif et production du savoir (Paris: Presse Universitaires de France, 1995); Antonella Romano, La contre-réforme mathématique: Constitution du savoir (Paris: École Française de Rome, 1999). Agustín Udías, Jesuit Contribution to Science: A History (Heidelberg: Springer, 2015), 1-22. 
mathematics and ancient languages in the Jesuit college at Würzburg. In 1633, he succeeded Christoph Scheiner (c.1573-1650) as professor of mathematics at the Roman College, where he spent the rest of his life. Kircher occupied the chair of mathematics for only eight years, after which he was free from all teaching duties and dedicated himself completely to his research and his enormous work as a writer with the publication of thirty-two books. Another important occupation was the organization of his celebrated museum with the construction of elaborate optical and mechanical machines. His books covered subjects as diverse as the Egyptian hieroglyphs, universal science, sound and music, China, the interior of the Earth, magnetism and the Tower of Babel. Kircher's books, most published in Amsterdam and Rome, were very popular, some running into several editions.

\section{$1 \quad$ Early Work on the Earth's Magnetic Field}

The existence of the Earth's magnetic field was known from early times by its applications to navigation using the compass. ${ }^{3}$ In the West, this was known from about the twelfth century, and maybe some centuries earlier in China. The first Western written document about terrestrial magnetism is by Alexander Neckam (1157-1217), dated about 1190. Magnetic declination (the angle between the direction of the compass and the geographic north) and its variation from place to place was observed by Spanish and Portuguese navigators from the fifteen and sixteen centuries and is described, for example, by Martín Cortés (1510-82) in his 1551 work Breve compendio de la sphera y de la arte de navegar (Short compendium about the sphere and the navigation art), where he clearly distinguishes between the geographic and magnetic poles. In 1581, Robert Norman ( $f$. 156o-85) published his discovery of the magnetic inclination or dip (the angle of the magnetic needle and the horizontal). In 16oo, William Gilbert (1540-1603) published his work De magnete (On the magnet), considered to be the first modern treatise on magnetism. He affirms, for the first time, that the Earth itself is a large magnet or loadstone, thus explaining the properties of compasses. In 1635, Henry Gellibrand (1597-1637) first discovered that magnetic declination changes with time, which is a consequence of what today is known as the secular variation of the geomagnetic field.

3 Brian Baigre, Electricity and Magnetism: A Historical Perspective (Westport, CT: Greenwood Press, 2007); Vincent Courtillot and Jean Louis le Mouël, “The Study of Earth's Magnetism (1269-1950): A Foundation by Peregrinus and Subsequent Development of Geomagnetism and Paleomagnetism," Reviews of Geophysics 45 (2007): 1-31. 
During the sixteenth and seventeenth centuries, Jesuit scientists also shared interest in the study of magnetism. ${ }^{4}$ The first was Leonardo Garzoni (1543-92), professor at the college of Venice, who sometime around 1580 wrote the work Trattati della calamita (Treatise on the loadstone), which was not published. ${ }^{5}$ In this work, Garzoni exposed the double polarity of magnets, their attraction of iron, and the orientation of magnetic needles pointing toward the Earth's poles. Garzoni's manuscript was used by Giovanni Battista della Porta (1535-1615), author of the popular book Magia naturalis sive de miraculis rerum naturalium (Natural magic or on the miracles of natural things, 1558), and Paolo Sarpi (1552-1623) in their work about magnetism. Through their work, Garzoni's ideas are thought to have influenced Gilbert. ${ }^{6}$ Nicolò Cabeo (1586-1650), Jesuit professor at Parma and Genoa, used Garzoni's manuscript to write up his Philosophia magnetica (Magnetic philosophy, 1629). Cabeo presented all that was known in his time about magnetism and added his own observations and experiments. He explained for the first time the relationship between magnetic and electrical attraction. He did not accept Gilbert's ideas about the origin of the Earth's magnetic field and erroneously maintained that magnetic declination was constant.

\section{Kircher's Works on Magnetism}

Kircher's interest in magnetism can be traced back to his early teaching at Heiligenstadt and the publication in 1631 of his first book on this subject, Ars magnesia (Magnetic art). ${ }^{7}$ Magnetism became from then on one of his preferred subjects. ${ }^{8}$ Ten years later, in 1641 , he published his definitive work on the subject, Magnes sive de arte magnetica (The magnet or the magnetic art, figure 2.1),

4 Pierre de Vregille, "Les jésuites et l'étude du magnétisme terrestre," Études 104 (1905): 495-511; Agustín Udías, "Jesuits: Role in Geomagnetism," in David Gubbins and Emilio HerreroBerrera, eds., Encyclopedia of Geomagnetism and Paleomagnetism (Dordrecht: Springer, 2007), 460-62, and Udías, Jesuit Contribution, 49.

5 Monica Ugalia, "Introduzione," in Leonardo Garzoni, Trattati della calamita a cura di Monica Ugalia (Milan: Franco Angeli, 2005), 7-83.

6 Ugaglia, "Introduction," 6o-68.

7 Athanasius Kircher, Ars magnesia (Würzburg: Elias Michaelis Zink, 1631).

8 William Hine, "Athanasius Kircher and Magnetism," in Fletcher, ed., A. K. Beziehungen, 79-97; Michael John Gorman, "The Angel and the Compass: Athanasius Kircher's Magnetic Geography," in Findlen, ed., Athanasius Kircher, 239-59; Oriol Cardus, "Kircher, Athanasius (16021680)," in Gubbins and Herrero-Bervera, eds., Encyclopedia of Geomagnetism and Paleomagnetism, 463-64. 


\section{A T H A N A S I I K I R C H E R I}

FVLDENSIS BVCHONII, E SOC.IESV.

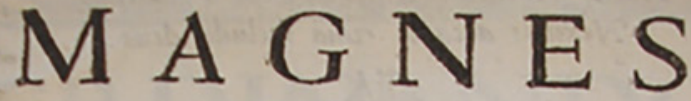

fiue $\mathrm{De}$

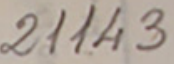

ARTE MAGNETICA OPVS TRIPARTITVM

(uio

PRATERQVAM QVOD VNIVERSA MAGNETIS

Natura, eiulque in omnibus Artibus \& Scientijs yfus nouz

methodo explicetur, è viribus quoque \& prodigiofis effectibus Magneticarum, aliarumque abditarum Natura motionum in Elementis, Lapidibus, Plantis \& Animalibus elucefcentium, multa hucufque incognita Naturx arcana per Phyfica, Medica, Chymica, \& Mathematica omnis generis experimenta recluduntur.
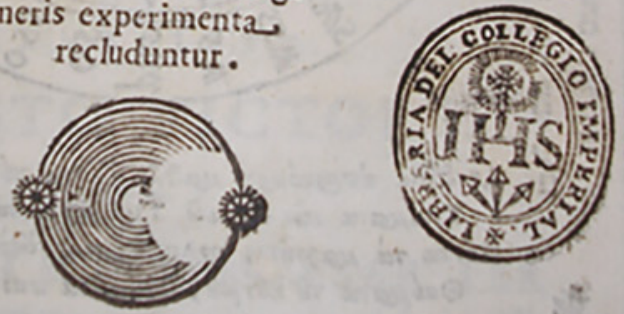

Sumptibus Hermanni Scheus fub figno Reginx. ROMAE, EXTypographia Ludouici Grignani . MDCXLI. SVPERIORVM PERMISSV.

FIGURE 2.1 Title page of the first edition of Athanasius Kircher, Magnes sive de arte magnetica (Biblioteca Histórica, Universidad Complutense, BH-DER 4558) 
dedicated to Emperor Ferdinand III (r.1637-57), and reissued in 1643 and $16544^{9}$ The second edition, only two years after the first, shows the rapid acceptance of the book. Magnes is a large book in folio size with 982 pages and many detailed engravings divided into three books: 1. De natura et facultatibus magnetis (Nature and capacities of magnets), 2. Magnes applicatus (Applications of magnets), 3. Mundus sive catena magnetica (World or magnetic chain). Magnetism reappears in 1664 in parts of Mundus subterraneus (Subterranean world) ${ }^{10}$ and in 1667 in Magneticum naturae regnum (The magnetic kingdom of nature).$^{11}$ In the preface to Magnes, Kircher insists on the universality of the magnetic phenomenon, which for him is present in all kinds of attractions and repulsions, sympathies and antipathies that occur in nature. He was aware that others had studied what they called "magnetic philosophy" (philosophia magnetica), but he preferred to talk about "magnetic art" (ars magnetica); that is, he wanted to join theory and practice and apply rules and experiments to them. Kircher treats both the nature and properties of magnets and of the Earth's magnetism.

Being aware of the difficulty of the subject, he begins calling the magnet "the great miracle of nature, labyrinth of philosophers and an impenetrable abyss." Kircher claims to use in his work a simple style, a "German candor" (germano candore), not one that was affected or rhetorical, as often used by other writers on the subject, even though he recognizes that the subject of magnetism is very abstruse. He maintains that his study was one of experimental philosophy, so that in his explanations he would not allow any supernatural or satanic elements, and he explains everything only from a natural point of view (sola vi naturae). He quotes above all Gilbert, "the first who has written on the nature of magnetism" and the works by Garzoni and Cabeo. Kircher's Magnes is divided into three books. The first deals with the properties of magnets, the Earth's magnetism, and the use of the compass. The second treats of different applications of magnetism, its relation to the heavenly bodies, and the distribution and origin of the magnetic declination and inclination. The third explores the cosmic influence of magnetism and its unifying

9 Athanasius Kircher, Magnes sive de arte magnetica: Opus tripartitum (Rome: H. Scheus, 1641); Kircher, 2nd edition (Cologne: J. Kalcoven, 1643); Kircheridem, $3^{\text {rd }}$ edition (Rome: B. Deversin and Z. Masotti, 1654). Quotations are given from the first edition.

10 Athanasius Kircher, Mundus subterraneus in XII libros digestus (Amsterdam: Apud Joannem Janssonium van Waesberghe, 1664; 1665; 1678).

11 Athanasius Kircher, Magneticum naturae regnum (Rome: I. de Lazaris, 1667); Kircher, Magneticum naturae regnum (Amsterdam: Apud Joannem Janssonium van Waesberghe, 1667). 
force that pervades the whole universe, linking it with the mystery of the Trinity.

First, it should be pointed out that although he often quotes his work, Kircher does not agree with Gilbert about many aspects of the Earth's magnetism. In particular, he does not accept that the Earth itself is a great magnet, as proposed by Gilbert, and defends the view that terrestrial magnetism is produced by veins of magnetic material on the Earth's surface oriented toward the north and south poles. Since Kircher did not accept the Earth's rotation, for him the north and south poles refer to the celestial poles of the rotation of the sphere of the fixed stars. According to him, it is precisely the influence of the celestial poles that orients the Earth's magnetism in their direction. For Gilbert, terrestrial magnetism was precisely related, in some way, to the Earth's rotation. Kircher also rejected the idea of Johannes Kepler (1571-1630), the discoverer of the three laws of planetary motion, that the revolution of the planets around the Sun was due to a magnetic force emitted by the Sun. According to Kircher, Kepler was a good mathematician, but he failed as a physicist. Kircher maintained, at least in public, the stable position of the Earth in the center of the universe in accordance with Aristotelian cosmology.

An interesting aspect of Kircher's work is his treatment of magnetic declination and its geographical distribution, which he called Geographia magnetica (Magnetic geography). He uses also for magnetic declination the word Chalyboclisin (derived from the Greek words Chalybes, a region famous for its iron work and klino, to incline), a word already in use, for example, by Simon Stevin (1548-1620) in his Hypomnemata mathematica (1608). Kircher treats magnetic declination in Magnes, book 2, part 5, Geographia magnetica (Magnetic geography), section 2, De variatione, seu declinatione magnetis a linea meridiana (About magnetic variation or declination from the meridian line). It is divided into six chapters. There, he sustains that it is widely accepted that the compass does not point exactly to the geographical north (defined by the Polar Star), but somewhat to one side or another (magnetica in polos dirigi [...] non praecise in polos colliment sed nonnihil ab iis alterutram partem deflectant) and adds that the origin of this deviation remains uncertain. He assigns the first observations of magnetic declination to the famous seafarers Sebastian Cabot (1484-1557) and Gonzalo Fernández de Oviedo (1478-1557). Kircher mentions that there are so many different opinions and uncertainties in the observations of magnetic declination so that it remains a very intricate problem 
(intricatissimoque magneticae variationis negotio). He affirms that it is necessary to reformulate geography from the point of view of terrestrial magnetism, using the observations of magnetic declination, but it is not clear what he means by this.

Kircher first rejects the opinions of Pedro de Medina (1493-1567), Spanish royal cosmographer and author of Arte de navegar (Navigation art, 1545), who assigned declination to errors of sailors' measurements, and of Pedro Nunes (1502-78), Portuguese mathematician and author of navigational works, who assigns it to errors in transmissions of data. As a general accepted fact, Kircher states that at the Azores Islands (at Corvo and Flores Islands) declination is zero. At that time, Corvo Island (present coordinates $39^{\circ} 40^{\prime} \mathrm{N}, 31^{\circ} 06^{\prime} \mathrm{W}$ ) was taken as the origin of longitudes; so Kircher gives longitudes of places respect to this origin (they must be subtracted 31 degrees to convert to present longitudes). From the Azores moving eastwards, declinations had values to the east of geographical north, and moving westwards to the west. Thus, he quotes values of declination in Plymouth (England) $13^{\circ} 20^{\prime} \mathrm{E}$ and in Brazil $12^{\circ} \mathrm{W}$. He states that in the values given for declination at different places there are many uncertainties and rejects della Porta's opinion that declination was everywhere constant with a value of nine degrees to the east (this is the value observed at that time in Italy). Kircher also says that observations do not support the famous physician-astrologer Girolamo Cardano (1501-76), who thought that declination was so many degrees from the world pole (polus mundi) apart from the Polar Star (about one degree). He quotes Adriaan Metius (1571-1635) and Stevin, giving values of declination at several places. Finally, he concludes that there is not a regular positive or negative change of declination with respect to longitude at different places (nullum esse magneticae declinationis regulare incrementum aut decrementum). Then Kircher concludes that it is not possible to use the observation of magnetic declination to determine directly longitudes at sea because its variations do not follow any law but are erratic, decreasing and increasing with longitude and latitude. ${ }^{12}$

The accurate determination of geographical longitude in long sea journeys was, at that time, an important problem. ${ }^{13}$ Unlike latitude, which can be easily

12 Cum nullam certam in declinando legem feruet magnes, sed erratica, nunc huc, nunc illuc divagatur, decrescendo nunc in longitudinem, nunc in latitudinem, nunc parum, prout conditio tulerit (The declination of the magnet does not follow any certain law, but an erratic one, changing here and there, in some places decreasing with longitude, in other with latitude, in other only a little, according to given condition). See Magnes, 314.

13 Rebekah F. Higgitt and Richard Dunn, Finding Longitude: How Ships, Clocks and Stars Helped Solve the Longitude Problem (Glasgow: Collins, 2014); William J. H. Andrews, 
determined by the observation of the position of heavenly bodies (for example, the height of the Polar Star or the Sun at noon), there are no such simple methods for longitudes. Awards were established by Spain, The Netherlands, France, and England for a reliable method. A common search at that time was the use of the observations of magnetic declination for this purpose. By 1667, the Royal Society of London under its secretary Henry Oldenburg (1619-77) had been considering this problem and finally gave up and decided on the use of the accurate determination of time. The problem was not solved until the development of the first accurate marine chronometer by John Harrison (1693-1776) in 1773 .

To solve the problem about the causes of the variations of the magnetic declination and their possible use to determine longitudes, Kircher collected as many observations as possible and their geographical distribution he called "magnetic geography." He affirms that it is necessary to reformulate geography from the point of view of terrestrial magnetism. Connected with this question, he proposes that Jesuits, taking advantage of their journeys around the world in their missionary work, should establish what he called a "geographical council" (consilium geographicum) in order to process the magnetic observations carried out by them. Thus, he describes instruments and methods for the accurate measurement of the magnetic declination and inclination or dip and discusses the problem of their relationship to geographic latitude and longitude.

Observations of Magnetic Declination

The collection of observations of magnetic declination occupies book 2, part 5 , section 2, chapters 2 to 4 and tables 1 to 3 , giving the values of declination in degrees and minutes of arc. Kircher begins that part of his work by recognizing that at his time practically the whole world was already widely traveled by Portuguese, Spanish, English, and Dutch navigators and seafarers, who often made magnetic declination observations. There were then available a great number of such observations, among them those made by the Jesuits, which will be treated in the next section. Chapter 2 treats observations on oceans, chapter 3 on the Mediterranean Sea, and chapter 4 in Europe and other places on land and sea. In chapters 2 and 3, there are two short lists with 10 and 15 values of declination, giving a description of the place where they are made. The first list

The Quest for Longitude: Proceedings of the Longitude Symposium (Cambridge, MA: Harvard University Press, 1996). 
of observations will be explained below, among those made by Jesuits. The second gives values of declination on the Mediterranean Sea from Italy to Egypt, made in 1638 by the Englishman Ioannes Gravius (John Gray?), "a man of distinguished judgment and experience" (vir iudicio et experientia conspicuous). For example, the list gives for Capo di Corso, Corsica, the value of declination $7^{\circ} 30^{\prime} \mathrm{W}$ and at Alexandria, Egypt, $5^{\circ} 45^{\prime} \mathrm{W}$.

Table 1 has the title "General magnetic declination of the oceans, from observations of Portuguese, English, and Dutch navigators, and others, taken from the works of mathematicians of the Society of Jesus." The table gives 197 observations together with values of latitude and a description of the places, giving sometimes the distance in leagues from some known place, for example, at a point 20 leagues from Canary Islands (the value of a league varies in different countries; a common value is three nautical miles, $3.45^{2}$ miles or $5.556 \mathrm{~km})$. East and west directions of declination are given by the Greek words anatlismos and dusismos, corresponding to the more often used Latin words of ortum and occasum (sunrise and sunset). No identification of the authors of the observations is given, but they are supposed to be taken from Jesuits' works. In the first part, there are observations by Portuguese navigators at places from Lisbon to the coasts of Central America and Brazil and around the coasts of Africa to India (Goa) and China (Macao); in the second part, there are observations from English and Dutch navigators made at higher latitudes in the Atlantic Ocean.

Table 2 presents the values of the observations mostly taken from Jean le Tellier (Telier or Ioannes Telierus, $f l .1620-50$ ), a French navigator and cartographer from Dieppe. ${ }^{14}$ The title of the table of Tellier's observations from his journey to the West Indies reveals the title of Tellier's book: Voyage fait aux Indes Orientales [...] reduit par lui en tables pour enseigner a trouver par la variation de l'aymant la longitude (Journey to the East Indies [...] reduced in tables to show how to find the longitude using the variation of the magnet, Dieppe, 1631). ${ }^{15}$ The table gives the values of longitude (with origin at the Azores), latitude and magnetic declination for places from Europe through the African

14 Sarah Toulouse, "Marine Cartography and Navigation in Renaissance France," in David Woodward, ed. The History of Cartography, vol. 3: Cartography in the European Renaissance (Chicago: The University of Chicago Press, 2007), 1550-68.

15 Tabula II. Longitudinum et latitudinum diversorum locorum, cum declinatione magnetis, quorum pleraque sunt observata a Ioanne Teliero in sua navigatione in Indiam Orient. (Table 2. Longitudes and latitudes of diverse places together with magnetic declination, most of which observed by Ioannes Telierus [Jean le Tellier] in his navigation to the East Indies). 
coast around Cape of Good Hope to India and South China Sea and from Europe to America. Values of magnetic declinations are separated giving first values to the east and afterwards values to the west, with a total of 215 observations. This is the only table where values of the longitudes of observation points are given. Kircher does not mention this table in the text, so we do not know how he valued the exactitude of the observations.

Table 3 contains eighty-one values of magnetic declination at different places (giving the name of the observer, place, latitude, and declination) made by sixty-seven different mathematicians, some at Kircher's request, forty-two of them Jesuits. Among the non-Jesuits we find the well-known Pierre Gassendi (1592-1655) and Marin de Mersenne (1588-1647) from France and Bonaventura Cavalieri (1598-1647) from Milan. An observation at London is taken from Gilbert, but no reference is given from where it was taken. Kircher considers that all the observations included are worth of credit as made by very good mathematicians. ${ }^{16}$ The three tables give a total of 493 observations of magnetic declination.

A great number of observations of the magnetic declination presented by Kircher were made by Jesuits and they merit special attention. The list with ten observations in chapter 2 were made by the Jesuit Martino Martini (1614-61), a missionary to China who had been Kircher's student in Rome. They were made in a journey intended to be from Lisbon to China, but because of bad weather, he only reached Cape Verde Islands and returned to Lisbon. In table 3, we find forty-three observations of magnetic declination made by Jesuits, mostly in Europe but also in India, China, and the Americas. The locations in Europe are plotted in figure 2.2, and those in Asia in figure 2.3.

Most observations come from German-speaking lands, France, and Italian Peninsula, where Kircher had more contacts. From outside Europe, there are

16 "Porro cum haec observationes a plerique eximiis mathematicis sint factae, non est quod de earum fide dubitemus; supponimus enim singulos ea cura et diligentia suscepti muneris partes obiisse, quantam rei gravitas, atque adeo ipsa posteritas, uniuscuiusque demum in inconcussam veritatem amor atque affectus merito postulare videbatur" [Also, we cannot doubt about their reliability, because these observations were made by many eminent mathematicians. We suppose that each one were made with that care and diligence that the importance of the subject and even posterity itself required, and how it seems to require the love and affection to truth]. See Magnes, 319. 


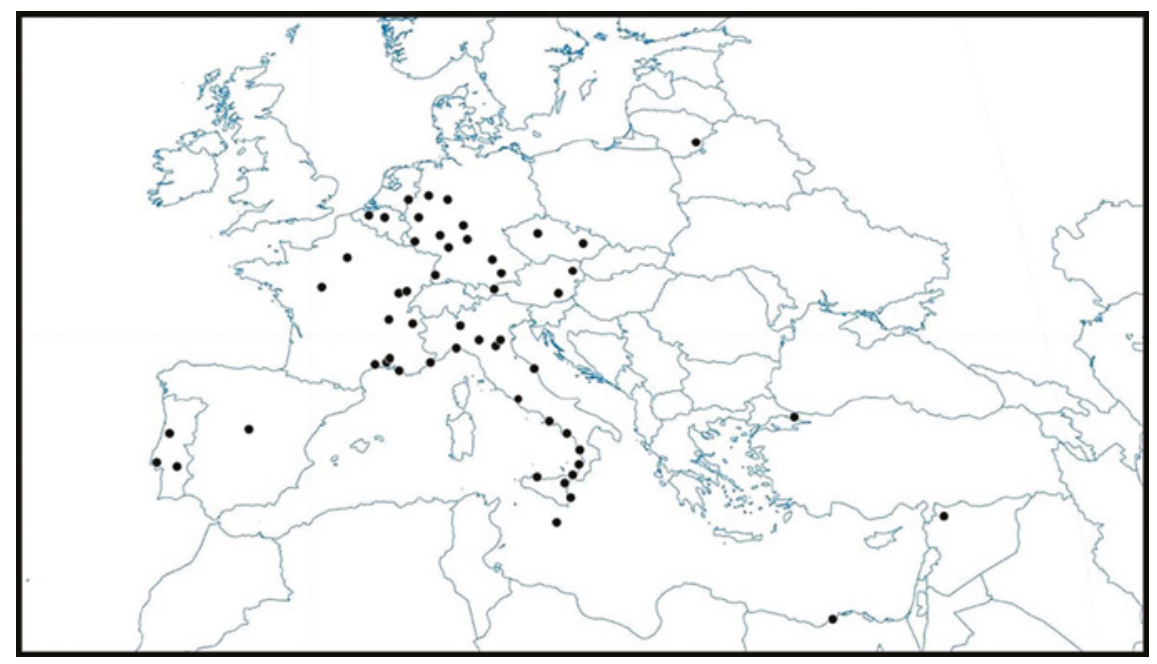

FIGURE 2.2 Observations of magnetic declination by Jesuits in Europe and the Mediterranean

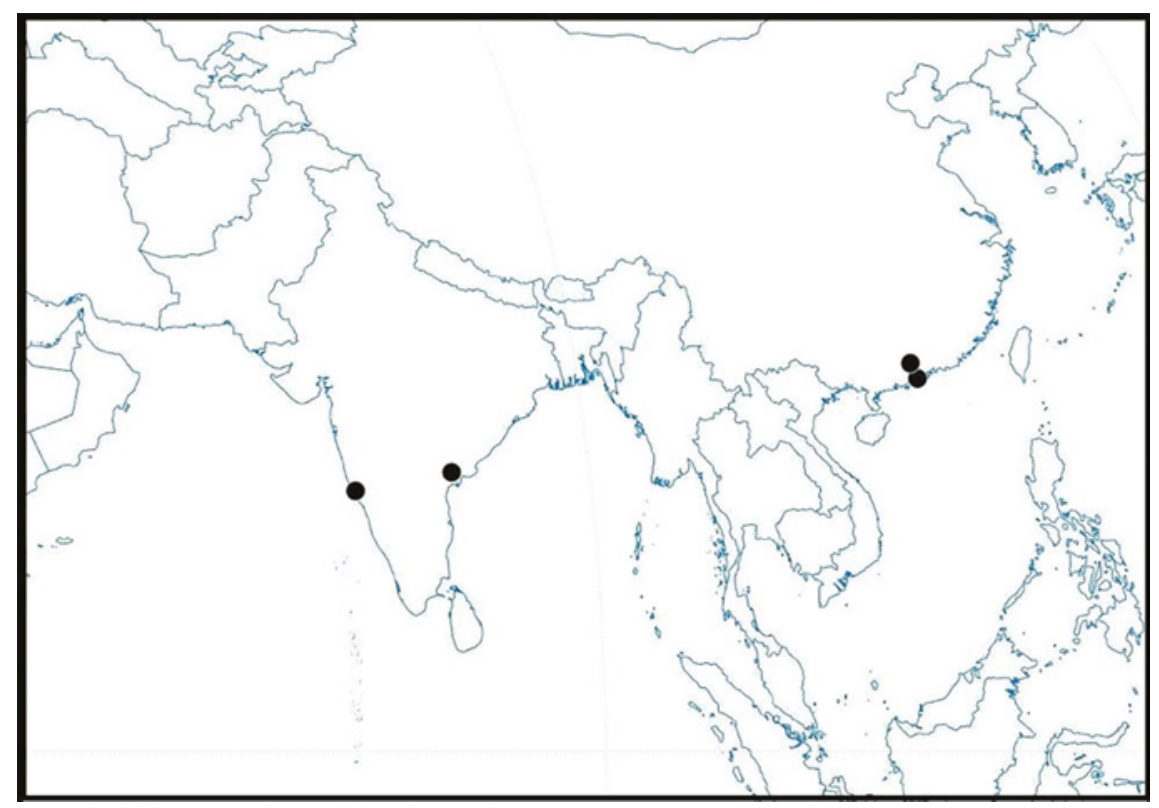

FIGURE 2.3 Observations of magnetic declination by Jesuits in India and China

only two observations in India (Goa and Narsinga) and two in China (Macao and Canton). Among the observers, some well-known Jesuit mathematicians are included, such as Jacques Gradami (1588-1672, Turon), Giovanni Battista Riccioli (1598-1671, Bologna), Cabeo (Ferrara), Giuseppe Biancani (1566-1624, 
Parma), Grégoire de Saint-Vicent (1584-1667, Gants), Scheiner (Silesia), Antonio Rubino (1578-1643, Narsinga, India), Ivan Vreman (1583-1620, Goa, Canton, Macao). Kircher himself contributed measurements at Fulda, Heidelberg, and Trier.

Kircher's account of Jesuit contributions to the study of terrestrial magnetism and to the observation of magnetic declination is not reduced to the names and data given in table 3 . We saw already the early work on magnetism by Garzoni and Cabeo. Long journeys in their missionary work to India, China, and the Americas provided an opportunity for Jesuits to make precise observations of the magnetic declination in those remote places. Kircher writes, for example, about a letter in 1609 by Giulio Alieni $(1582-1649)$ from China to Clavius. Alieni tells Clavius of his measurements of the magnetic declination during his journey to China, obtaining values to the east along the west coast of Africa from the Equator to the Cape of Good Hope, zero at the Cape of Agulhas (South Africa) and afterward values of declination to the west from there to Goa, where the value was $16^{\circ} \mathrm{W}$. Clavius's successor Grienberger received a letter from Vreman in 1616 about his journey from Lisbon to Goa and then to Macao. In these two cities, he observed declination $16^{\circ} \mathrm{W}$ and $1^{\circ} 30^{\prime} \mathrm{W}$, respectively. In 1638, Kircher himself received letters from Martini with values of magnetic declination made along his journey, this time completed, from Lisbon to Goa and Macao.

6

\section{The Magnetic Map}

Kircher's mention of a magnetic map is found in book 2, part 6, Nautica magnetica, problem 6, dedicated to methods to find the longitude of a place. ${ }^{17} \mathrm{He}$ refers to the work by the Italian Jesuit Christoforo Borri (or Burrus, 1583-1632) on the determination of longitudes using magnetic declination. ${ }^{18}$ Borri, a controversial figure for his cosmological ideas, began as a professor of mathematics in Milan in 1609 and went in 1615 to Goa and Macao and in 1617 to Cochinchina (Vietnam) to return to Coimbra in 1624. Borri's method consisted in annotating values of magnetic declination at different meridians on a

17 Utrum et quomodo longitudo terrestris investigari possit [If and how the terrestrial longitude can be investigated]. See Magnes, 503.

18 Maurício Gomes dos Santos, "Vicissitudes da obra de Cristovão Borri," Anais da Academia Portuguesa da História 2, no. 3 (1951): 119-50; Michel-Pierre Lerner, "L'entrée de Tycho Brahe chez les jésuites ou le chant du cygne de Clavius," in Girard, ed., Jésuites à la Renaissance, $145^{-85}$ and note 36 . 
geographical map (mappa geographica) and uniting the points with equal declination value by lines he called tractus chalybocliticu s. From these lines Borri claimed he could determine with absolute certainty (infallibiliter) by the observation of the declination in the map, the position (geographical coordinates?) of a determined place and the distance to another place of different declination. No such map by Borri has been found, so we do not know if he ever produced it. Borri's original work describing his method has not been preserved either. We only have Kircher's discussion of Borri's work. Borri also contributed to table 3 with measurements of declination at Coimbra and Madrid.

Kircher calls this type of map with the values of declination a "magnetic map" (mappa magnetica). He writes that he could draw one such map using the values of declination obtained by the worldwide observations, "made by eminent geographers, navigators and mathematicians," and given in his tables. This map, he states, could be used if anyone would like to follow this method (Borri's method?) to find longitudes from the values of declination. Then Kircher describes how one could make one such a map using the values of the magnetic declination from his tables, plotting them in a geographic map and joining by lines those of equal value of declination. ${ }^{19}$ Kircher adds that he would gladly (libenter) present such a map here, if the cost and other concerns would allow him to do it. ${ }^{20}$ It is regrettable that he did not do it because it would have been the first magnetic map ever published. The first world magnetic map was eventually published by Edmond Halley (1656-1742) in 1701. Halley's map represents the values of magnetic declination at the Atlantic Ocean, using values he had collected himself during two journeys together with values by other navigators. ${ }^{21} \mathrm{He}$ seems to have ignored Kircher's work and did not use the values of declination from his tables.

Kircher failed to draw a magnetic map with the 518 values of magnetic declination given in the three tables and the two short lists. However, these values provide a good base for drawing such a map. Figure 2.4 shows the resulting map with the points where the observations were made and the resulting

19 "Delineetur orbis terrae figura quam aptiorem indicaverint, plane vel spherica et ex tabulis nostris magneticis singulis locis addantur declinationes propiae, quibus peractis ducito per omnia ea loca, quae homonimos declinationis gradus habent lineas" [Draw a map of the world as suitable as possible, either plane or spherical, and from our tables add the magnetic declinations proper of each place. Once this is done draw lines through all those places with the same value of declination]. See Magnes, 504 .

20 "Si et sumptus et prepropera impressio, negotiaque varia id permisissent" [If cost and consequent impression and several occupations would allow it]. See Magnes, 503-4.

21 Lori L. Murray, "The Construction of Edmond Halley's 1701 Map of Magnetic Declination” (PhD diss., University of Western Ontario, 2012). 


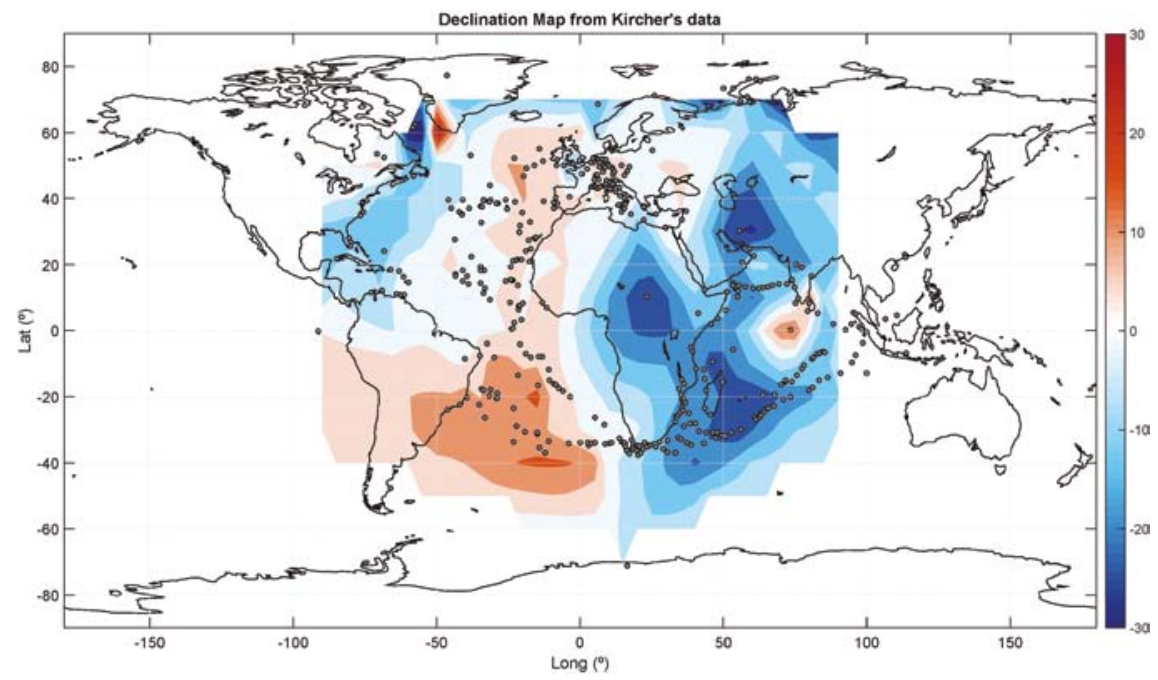

FIGURE 2.4 Map of magnetic declination from the values given by Kircher (red [positive] to the east and blue [negative] to the west) (Osete et al., unpublished, 2017)

interpolated values of declination (red [positive] to the east and blue [negative] to the west). ${ }^{22}$ Since magnetic declination varies with time, this map can be assigned to the year 1638 , taking that year as representing when most of the observations were made. The map shows the zero value of declination passing through the Azores and values to the east in Europe and south of the Atlantic Ocean and values to the west near the coasts of North America and in the Indian Ocean. This declination map agrees with the expected values given by the GUFM1 model for the "epoch" of 1638 , that is, a time period centered on that year. ${ }^{23}$ The map given in figure 2.3, although representing Kircher's values, is not, naturally, the map he could have drawn, because the map of the figure has been made using modern methodology of interpolation and representation. Kircher would have just drawn on the geographical map lines passing through points of equal values of declination.

22 María L. Osete, Francisco J. Pavon, and Agustín Udías, "A New Declination Chart for 16001640 Based on Athanasius Kircher Compilation" (CapeTown SA: IAPSO-IAGA Assembly, 2017).

23 The GUFM1 model is based on the compilation using 3,09o declination data for the time period between 1600 and 1640 . Andrew A. Jackson, Art R. T. Jonker and Matthew Walker, "Four Centuries of Geomagnetic Secular Variation from Historical Records," Philosophical Transactions Royal Society, A: Mathematics, Physics and Engineering Sciences 358 (2000), https://royalsocietypublishing.org/doi/abs/10.1098/rsta.2000.0569 (accessed September 8, 2019). 
Kircher discusses the problem of the causes of magnetic declination in section 2 , chapter $5 \cdot{ }^{24} \mathrm{He}$ begins disproving shortly some opinions, namely, those by Marsilio Ficino (1433-99), who assigned it to the influence of the stars of the constellation Ursa Minor, by Bessardo Galio (?) to the poles of the Zodiac, by Livio Sanuto (1520-76) to some kind of magnetic meridian, by Francesco Maurolico (1494-1575) to an unknown magnetic region, by Giulo Cesare Scaligero $\left(1494^{-1558)}\right.$ to the sky and mountains, and by Norman to the conditions at the respective places where observations are made. He dedicates more attention to three other causes: the weakness of the magnetic attraction on the needle of the compass, the influence by so-called "magnetic mountains" and the attraction by a certain celestial point.

Kircher dedicates a detailed analysis to Gilbert, calling his findings "distinguished heresy in magnetic philosophy" (insignis sane in philosophia magnetica haeresis $)^{25}$ First, as already mentioned, he denies Gilbert's main conclusion that the Earth itself is a large magnet (Magnus magnes sive terrestris globus), which he had arrived at from the experiments of using a small sphere of magnetite to compare its magnetic behavior with that of the Earth. Then Kircher also refutes the idea that the variations of declination are due to the influence of local variations in topography (large mountains and oceans), pointing to the values given in his tables that do not follow this distribution. After this, he proceeds to present his opinion on the "true" cause of magnetic declination. ${ }^{26}$ For Gilbert, who accepted the Copernican system, there was a certain relation between the magnetic poles and the axis of rotation of the Earth, so that both coincide. For Kircher, who still embraced geocentric cosmology and did not accept the rotation of the Earth, the magnetic poles were produced by the cosmic influence in the direction of the axis of the world, that is, the axis of the celestial sphere of the fixed stars, which points to the Polar Star. ${ }^{27}$ He proposes the existence of magnetic dikes (fibrae magneticae) under the oceans converging to the poles, which he claimed were the cause of the Earth's main magnetic

24 "Caput V. Disquisitio causarum declinationis magneticae" [Chapter 5 , Inquiry about the causes of magnetic declination], in Magnes, 330 .

25 Magnes, 332-36.

26 "Verae delinationis causae inquisitio" (Investigation of the true cause of declination). See Magnes, 336-39.

27 "Terram universam Magneticam vim obtinere, totamque polaliter compactam, coagmentataque per ordinem ad polos confirmari" [The whole Earth acquires magnetic force and is compacted and joint together with respect to its polarity by its relation to the poles]. See Magnes, 336. 
field. The irregularities in these dikes, which part a little from the general direction toward the north and south poles, explains the deviations from the meridian of the magnetic declination. ${ }^{28}$ What neither Kircher nor Gilbert could imagine was that the magnetic field of the Earth is in fact caused by the magneto-hydro-dynamic processes of the motion of the material in the Earth's outer core. ${ }^{29}$

In book 3, entitled Mundus magneticus sive catena magnetica (The magnetic world or magnetic chain), Kircher takes the bold step of considering magnetism not only as a physical force, but as a cosmic one, of both material and spiritual nature that pervades everything and finally has its origin in God. Thus, he proposes that all elementary and hidden qualities, all the motions of sympathy and antipathy present in nature are really manifestations of the cosmic and spiritual force of magnetism. For these considerations he based himself on the idea of the "Sefirot," which according to the Jewish Kabbalah are the ten emanations or attributes of the divine, which as celestial influences govern everything in creation. Kircher identifies these influences with magnetism and sees them as links or concatenations, which through the cosmic force of magnetism unite everything. He considers them to be similar to the "tree of life" of the Sefirot that he had discussed in his work Oedipus Aegyptiacus. ${ }^{30}$ In this universal concatenation, Kircher includes the magnetism of the planets, the meteors, the Sun and the Moon and their influence on the sea, plants, and animals. He states that a certain magnetic force is internally present in all elements and is the origin of all the processes that take place in the world. Thus, magnetic forces are present in plants (phytomagnetismus) and animals

28 "Quod subiectae sibi in fundo maris diffusae terrestres magnetico vigore imbutae partes, sive fibrae magneticae, ita ferantur [...] non enim omnes totius telluris partes, ita praecise et mathematice in polos dirigi, quin ab eis aliquantulum deflectam" [(Magnetic declination) so behaves because it is subject to parts or fibers impressed with magnetic force distributed in the bottom of the sea (...) not all parts of the whole Earth are directed to the poles in a precise and mathematical form, but they deviate somewhat from them]. See Magnes, 337.

29 Ronald T. Merrill, Michael W. McElhinny, and Phillip L. McFadden, The Magnetic Field of the Earth: Paleomagnetism, the Core, and the Deep Mantle (London: Academic Press, 1996).

Athanasius Kircher, Oedipus A egyptiacus, 3 vols. (Rome: V. Mascardi, 1652-54). 
(zoomagnetismus), and they are the cause of many strange and curious phenomena he often uncritically accepts.

Finally, Kircher ends his book identifying magnetism with love (Erotomagnetismus sive de magnetismo amoris), which is for him the force and origin of all the movements of attraction that keeps everything in proper order. All these movements and attractions have their ultimate origin in God, so that in the epilog he can call God "the central magnet of all things" (Deus rerum omnium centralis magnes). Kircher went even further and linked this unifying motion with the Christian mystery of the Trinity, in which everything is attracted to God the Father through the Eternal Truth (the Son) by the unifying force of the Spirit, constituting the "uni-triune magnetic principle" (Unitrino principio magnetico). In this form, he finally concludes that all creation is attracted by the force of love toward God-center and magnet of everything. It is difficult to judge with our modern mentality this part of Kircher's book, although it occupies almost half of the total text (four hundred pages). But we even today speak of such a thing as "personal magnetism." For Kircher these considerations correspond to a real continuity with the physical properties of magnets and the behavior of compasses on the Earth. We can only see them as an expression in metaphorical language of all actions of attraction and repulsion that may be finally considered to have its origin in the divine.

\section{Conclusions}

Kircher dedicated three books and parts of others to the phenomenon of magnetism he considered in very inclusive way, not only from the physical point of view but also as a cosmic and spiritual force. Terrestrial magnetism and the problem of magnetic declination was an important part of his work, where he limited himself to experimental aspects. Kircher collected a large number of worldwide observations of declination, many made by Jesuit missionaries in their long ship journeys and proposed representing them in a "magnetic map." Regretfully, he failed to draw such a map, which would have been the first one before that published by Halley in 1701. He discussed the possibility, mentioned by Borri, that such a map could help in the determination of longitudes, although he was not so sure about it. A map from his observations is presented here and it agrees with other determinations of the Earth's magnetic field for that age. Kircher's acceptance of the traditional geocentric cosmology prevented him from accepting Gilbert's main thesis that the Earth itself is a magnet, 
the basic tenet of modern science of terrestrial magnetism. That led him to a wrong explanation of the origin of magnetic declination. Finally, he went beyond the physical problem and considered magnetism as a cosmic and spiritual force that permeates everything and finally identifies with love with its origin in God. 